\title{
Politeness Strategies in Directive Speech Acts in Local Indonesian Parliament Assembly Proceedings
}

\author{
Kuncoro Dibyo Sarjono Maskuri ${ }^{1}$, Samiati Tarjana ${ }^{1}$, Djatmika $^{1} \&$ Dwi Purnanto ${ }^{1}$ \\ ${ }^{1}$ Postgraduate Program in Linguistics, Sebelas Maret University, Surakarta, Indonesia \\ Correspondence: Sri Kuncoro Dibyo Sarjono Maskuri, Doctor Candidate, Postgraduate Program, Sebelas Maret \\ University, Jl, Kentingan 32A Surakarta, Indonesia. E-mail: dibyomaskuri@gmail.com
}

Received: January 8, 2019 Accepted: February 18, 2019 Online Published: April 6, 2019

doi:10.5539/ijel.v9n3p85 URL: https://doi.org/10.5539/ijel.v9n3p85

\begin{abstract}
This study reports on politeness in directive speech acts appearing within the proceedings of the local parliament for Sukoharjo, Indonesia. The aim is to explain the politeness strategies used to convey intended persuasive forces during parliamentary discourses. Drawing upon the pragmatic qualitative approach, this study examined 18 parliamentarians and data on their previous utterances' form, function, meaning, and context in the proceedings. Using data collected through observation, records, and documentation, it looks at how the politicians acted. The results show that directive acts represent the main performance, with 154 tokens of illocution and 44 directive speech acts for politeness. Politeness strategies to perform directive speech acts are colored with on record, positive politeness, and aversion-to-acting negative politeness. The characters for positive politeness include inviting-gentle-direct, repressing-gentle-direct, suggesting-gentle-indirect, repressing-gentle-indirect, gentle-indirect, and respecting direct. This study implies pragmatic analysis in a different setting where an emphasized degree of formality is required. Suggestions are made to compare or contrast with utterances in less formal interactions, such as in the negotiations between a buyer and seller, and in religious circumstances like sermons in a mosque, church, or colloquial proceedings.
\end{abstract}

Keywords: pragmatic, directive speech act, politeness strategy, utterance character, parliament proceedings

\section{Introduction}

The subject of this research is the speech acts performed by members of the Parliament Assembly in Indonesia, focusing on the use of politeness strategies in directive speech acts. For politicians, speech is a pivotal tool and mode of communication, and it functions as a medium through which to express their views, opinions, and the decisions they make as law makers. According to Ayeomoni and Akinkuolere (2012, p. 461), "Most activities performed by politicians are done through the avenue created by language." Parliamentarians promote their views through various speech acts in order to influence their colleagues during parliamentary debates and convince the public about their points of view. These expressions should be delivered in a procedural manner, as is customary in parliamentary standards and the system it uses. It is therefore crucial for politicians to be skilled with using politeness strategies in their choice of language to realize this goal (Palonen, 2016).

One way to persuade others in political discourse is to use politeness in directive speech acts through direct and indirect speech. Huang (2007, p. 115) considers indirect speech acts to be politer than their direct counterparts because they are broadly connected to politeness. The polite use of language from parliamentarians should therefore also reflect their stated views when they interact or communicate in the daily parliamentary proceedings. Jarraya (2013) indicates that when there is tension, persuasive linguistic strategies should not be employed on their own but rather used in combination with other non-linguistic devices, like the speaker's personality and a sound grasp of the sociopolitical context. According to Langton (1993), the ability to perform various speech acts can be an indication of political power. Powerful politicians can often say more and be more dominant in their speech, for example.

The strategy of polite utterances applied in the current study refers to the taxonomy of Brown and Levinson (1987), which emphasizes five strategies: on record, positive, negative, off record, and silent or don't do face threatening act. Specifically, this study describes what directive politeness strategies are and how all five strategies occur in the interactions between members in the local parliament. The use of a strategy for directive speech acts arouses a certain reference to implicature theory. Grice (1967, cited by Thomas, 1995, p. 57), 
introduced the notions of conventional and conversational implicature, where conventional implicature is associated with specific words that, when used, convey extra meaning (Yule, 1996, p. 45).

Conversational implicatures include generalized conversational implicatures and particularized conversational implicatures. A generalized conversational implicature occurs without requiring a certain context, while the particularized conversational implicature needsa certain context (Huang, 2007, p. 31). Utterances basically have certain characteristics or features, much like a physical object. For example, paper has the characteristics of being thin and flexible. Likewise, an utterance has certain characteristics that indicate its meaning or reveal its intended interpretation. Oneexample in Indonesian of a directive politeness utterance is the phrase "Tolong, jelaskan pemakaian anggaran pembangunan itu" ("Please explain the use ofthe development budget"). Thishas a different character from "Pemakaian anggaran pembangunan itu seperti apa?" ("What did the use of the development budget look like?"). In fact, the character of the directive politeness utterance is not only affected by the decision to act politely, but also by the shape and function, the implicature, and its context.

With this background in mind, the current study first highlights the strategy for politeness utterances that is employed by the members of the local parliament of Sukoharjo (henceforth referred to as DPRD Sukoharjo) in its meetings, specifically in the budgetary meeting. It also looks at the characteristics of directive politeness utterances happening due to the directive politeness strategy being used by the speakers. This study therefore seeks to answer the following research questions:

1) What strategies for directive politeness utterances are used by members of DPRD Sukoharjo?

2) What are the characteristics of the directive politeness utterances spoken by the members of DPRD Sukoharjo?

\section{Literature Review}

The phenomenon of linguistic politeness has attracted considerable attention from various points of view for more than thirty years. Brown and Levinson's (1987) politeness theory is considered significant in linguistic pragmatics and has had a great deal of influence on politeness research. In using language politely, the local parliament members comply with the regulations and ethical code of DPRD Sukoharjo. These rules generally clarify the principles for communication in that parliamentary members must address each other politely and appropriately both within and outside parliamentary meetings. The principles for communication in DPRD Sukoharjo are equivalent to politeness concepts from linguists, such as Leech's (1983) Politeness Principles, Brown and Levinson's (1987) Politeness and Face, Lakoff's (1990) Rules of Politeness, and Gunarwan's (2007) Harmony Principle.

Due to the regulations and ethical code for interaction, the members of DPRD Sukoharjo are obliged to use language politely. Using language politely is affected by certain social factors, thus illustrating the social relation between a speaker and a hearer. Brown and Levinson (1987) list three social factors: social distance, relative power, and the weight of imposition of the utterance. These assumptions are based on the concept of the interpersonal function of language from Halliday (1973), namely that language functions as an expression of speaker attitude and its influence on the attitude and behavior of the speaker (Leech, 2011, p. 86).

Previous related studies about politeness in language use and directive speech acts are referred to in this study. Such previous studies include Positive Politeness Strategies in Everyday Japanese Conversation by Shigmitsu, Murata, and Otsuka (2006); Politeness, Gender, and the Face of the Speaker by Karafoti (2007); Politeness Strategies of Chinese and American Speakers by Cheung (2009); Perilaku Tindak Tutur Berbahasa Pemimpin Dalam Wacana Rapat Dinas: Kajian Pragmatik Dengan Pendekatan Jender (Speech Acts in Language Usage by Office Leaders in Official Meetings) by Prayitno (2009); Face Threatening Act and Standing Orders: 'Politeness' or 'Politics' in the Question Time Discussion of the Kenyan Parliament by Ambuyo, Indede, and Karanja (2011); and Politeness Strategies in Openings and Closings of Service Encounters in Two Malaysian Agencies by David, Kuang Chei, and DeAlwis (2012).

A comprehension of politeness as a strategy to avoid conflict can be found in the idea of Brown and Levinson (1987), who suggest that the essential function of politeness is to control a potential conflict between interacting parties. The politeness approach, as proposed by Brown and Levinson (1987), is a development of Goffman's idea (1959) about the concept of face and the politeness rule of Lakoff (1973). It accentuates two distinctive types of face for both speakers and listeners: the positive face and negative face. The concept of face here does not refer to a person's physical facial appearance but rather his or her public image or dignity. The positive face refers to a person's desire to be liked by others, while the negative face refers to a desire to not have his or her actions hindered by others (Brown \& Levinson, 1987, p. 67). The positive face therefore represents a person's 
wish to be accepted and admired by others and a desire to have a shared common ground with the social group. The negative face, in contrast, indicates a desire for freedom without interference from others.

In a similar way, politeness has positive and negative aspects. Positive politeness is oriented toward the positive faces of other people in agreement, emphasizing how both speakers want the same thing and so share a common goal (Yule, 1996, p. 62). Negative politeness, meanwhile, is performing a face-saving act that is oriented toward another's negative face. It is an expression of a minimal intervention, which tends to "emphasize the importance of the other's time or concerns, and even include an or the imposition or interruption" (Yule, 1996, p. 62).

The face concept requires certain values to be maintained, and this calls for politeness strategies, such as using language politely in order to not break down values (Brown \& Levinson, 1987). A politeness strategy is used when a face-threatening act occurs in an interaction. The politeness strategy of Brown and Levinson (1987) includes five acts:

- On Record: a speech act given directly and without lip service

- Positive Politeness: an expression of solidarity, friendliness, and in-group reciprocity

- Negative Politeness: a speaker's restraint and avoidance of imposing on the listener

- Off the record: performing a speech act indirectly

- Silent or Do not do FTA

Goody (1987, pp. 101-129) lists 15 subcategories of positive politeness strategies: (1) to notice and attend to the hearer (e.g., his/her interests, wants, needs, goods); (2) to exaggerate (e.g., show interest, approval, or sympathy for the hearer); (3) to intensify interest to the hearer; (4) to use in-group identity markers; (5) to seek agreement; (6) to avoid disagreement; (7) to presuppose /raise/ assert common ground; (8) to joke; (9) to assert or presuppose the speaker's knowledge of, and concern for, the hearer's wants; (10) to offer or promise; (11) to be optimistic; (12) to include both the speaker and hearer in the activity, (13) to give (or ask for) reason; (14) to assume or assert reciprocity; and (15) to give gifts to the hearer. In addition, Goody (1987, pp. 132-210) identifies 10 subcategories of negative politeness: (1) to be conventionally indirect, (2) to question or hedge, (3) to be pessimistic, (4) to minimize imposition, (5) to give deference, (6) to apologize, (7) to impersonalize the speaker and hearer, (8) to give a face-threatening act as a general rule, (9) to nominalize, and (10) to go on record as incurring a debt rather than being an indebted hearer.

The study of politeness in language use is closely related to pragmatics. Levinson (1983, p. 12) defines pragmatics as the study of the aspects of meaning not covered by semantic theory. This notion implies that pragmatics studies the meaning of a language unit externally, whereas semantics studies the lexical meaning of language internally, separate from the situation and context. Levinson (1983, p. 21) also explains that pragmatics is the study of the relations between the use of language and the context, and such relations are fundamental to understanding language. This definition includes the notion that the context is used to comprehend the background knowledge of the speaker and hearer, the situation in which an interaction event occurs (the where, when, and how), and what the speaker and hearer is talking about or presupposing. In addition, Leech (1993, p. 8) states that pragmatics is concerned with meaning with regards to the speech's situation. Speech act processes are determined by the context of an utterance, with such contexts being called aspects of the speech situation. These include (i) the speaker and hearer, (ii) the utterance context, (iii) the goal of the utterance, (iv) the utterance as a speech act (i.e., its locution and illocution, and (v) the utterance as the product of a verbal act (i.e., perlocution) (Leech, 1993, pp. 19-20).

The ultimate idea behind a speech act is that language use not only illustrates phenomena in the factual world but also does things. Austin (1954) describes this as "how to do things with words." The directive speech act hypothesized by Searle (1976) aims to elicit an act by the hearer through the speaker's directive utterance. Speech act theory can help analyze utterances from the view point of their functions rather than their form. A speech act, according to Searle (1976), comprises the assertive, directive, commissive, expressive, and declarative. A directive speech act can involve commanding, requesting, inviting, forbidding, suggesting, and so on (Cutting, 2008, p. 15). Leech (1993, p. 164) categorizes it as a competitive speech act requiring negative politeness. Gunarwan (2007, p. 27), meanwhile, formulates a directive speech act as a speech act performed by a speaker to make the listener do something. A direct or indirect utterance can be used in a directive speech act, with a direct utterance using the imperative mood and indirect utterances using anon-imperative mood.

\section{Methods}

This study employs a qualitative approach with an in-depth description of the politeness appearing in directive 
speech acts from the proceedings of DPRD Sukoharjo, Indonesia. These proceedings cover a discussion among parliament members about the use of the development budget. A qualitative approach was used to gain a thorough understanding of these speech acts. The sample was selected using purposeful sampling techniques and comprised 45 members, 18 of which were members of the budgetary board. Data were collected through observation, interviews, and documentation for each of the recording transcripts. The researcher identified speech acts that employed politeness devices and were used by parliament members during the proceedings.

Specifically, data were collected through the passive participation of observation, whereby the researchers attended the parliamentary proceedings but did not participate in the interactions. The researchers directly observed the communication occurrences and speech strategies delivered by each member of parliament. The utterances of parliament members were also recorded and field notes were taken to highlight any utterances indicating politeness strategies during the proceedings. Such utterances were later transcribed into written form for analysis. Documentary records of previous events - such as anecdotal notes, letters, or diaries, whether written or printed - were used to add more comprehensive information (MacMillan \& Schumacher, 2001, p. 42).

Furthermore, the data were analyzed using the modified ethnography model of Spradley (1980, p. 103), and framed as the Development Research Sequence. The modified sequences refer to Santosa's (2012, p. 54) model, including the domain analysis sequence, component analysis sequence, and sequence of making a theme analysis. The data for politeness utterances were analyzed using the pragmatic identity method (Sudaryanto, 1993, p. 15), the dividing-key-factor techniques employing pragmatic-competence-in-dividing, and the read-marker technique to look over the denoted marker directly (Sudaryanto, 1993, p. 95).

\section{Findings and Discussion}

The data examined in this study comprise the politeness utterances in directive speech acts by the members of DPRD Sukoharjo. The proceedings involved achieving agreement for the annual budget of the local government of Sukoharjo Regency.

The results reveal 154 utterances of illocution, 44 directive speech acts of politeness, the shape of directive utterances, the strategy used to perform directive speech acts of politeness, and the context of the utterances when viewed through the pragmatic approach. This study focuses on illocutionary directive utterances and excluded other illocutionary acts, such as assertive, expressive, commissive, and expressive acts. In addition, the focus of the analysis included the strategy for directive politeness utterances and the characteristics of directive politeness utterances when performed by parliament members. More specifically, utterances were addressed from the view of the speakers who argued and expressed ideas during the proceedings.

\subsection{The Context of Directive Politeness Utterances}

The context of utterances relates to speech events (the place, time, and situation of a meeting), the topic and objective for the parliamentary meeting, and the speakers' backgrounds as parliamentarians. The setting here is the proceedings of the Budgetary Board of DPRD Sukoharjo, as conducted in the main meeting room (the Paripurna meeting room) of the parliament building. Held in a formal style, the meeting discussed the budget report of DPRD Sukoharjo.

The local parliament oversees the function and performance of the local government for Sukoharjo Regency. The parliamentary meeting of the Budgetary Board was attended by the board chairman, three vice chairmen, the secretary, and thirteen other members of the Budgetary Board. They, as members of the legislature, represent parliament's controlling role over government as the executive institution. Debates and tensions may manifest because the attendees have different political backgrounds and come from different local parties.

\subsection{Politeness Strategies in the Directive Speech Acts of Members of Parliament}

Four parliamentary members with various social backgrounds commented on the report delivered by the executive officer during the proceedings. Table 1 suggests that this shows three of the five types of politeness strategies put forward by Brown and Levinson (1987), indicating the social background of the speakers. 
Table 1. Politeness strategies in the directive speech acts of parliament members

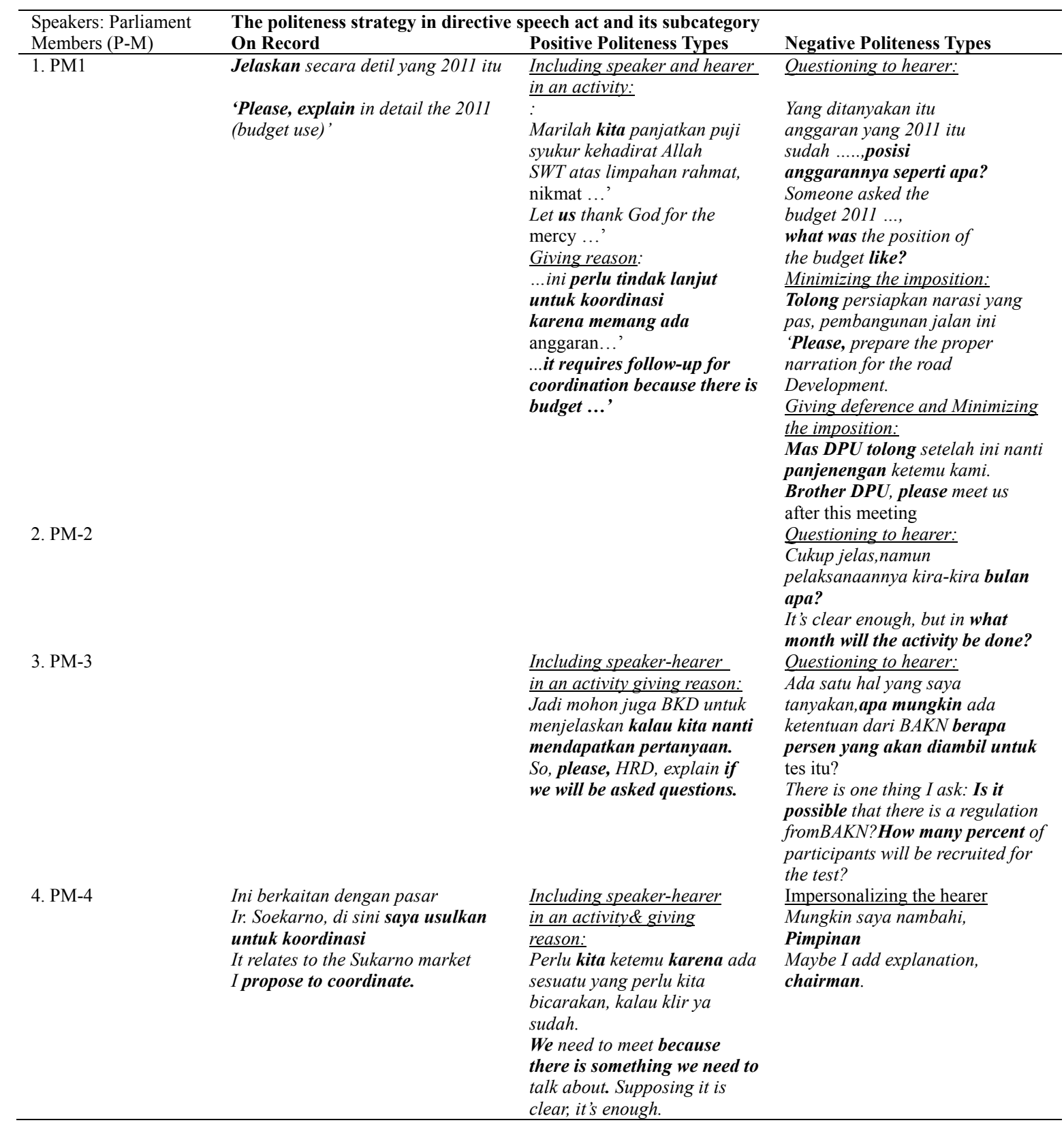

The evidence shows how politeness utterances come from Speaker-PM1, who as chairman needs to moderate the flow of interaction. More power and opportunities to control the atmosphere of the proceedings are used, thus dominating over the entire interaction. The three strategies employed are on record, positive politeness, and negative politeness, while the strategies off record and silent were not used.

The positive strategy includes two sub-strategies, including the hearer and speaker in the activity and giving reason. The negative strategy, meanwhile, involves four sub-strategies: questioning or hedging, minimizing the imposition, giving deference, and impersonalizing the speaker and hearers. It implies that legislatures tend to copy positive and negative strategies in formal settings during proceedings.

In addition, two directive speech acts manifest through the on-record strategy, as performed by speaker-PM1 and speaker-PM4. The on-record strategy in directive speech acts involves a direct imperative or instruction from a speaker to a hearer, indicating that speakers in the parliament meeting (the legislature) had more power than the hearer (the government officer representing the executive).

The politeness strategy for directive speech acts by the parliamentary members derived from the illocutionary 
directive act, which has a certain lingual shape and function. This way, the politeness utterances of directive speech acts could be identified through the politeness markers used by the speakers. Table 2 shows example illocutionary utterances and directives, the markers of the politeness utterance, the shape of the directive utterance, and its function.

Table 2. Example illocutionary utterances and politeness directives made by the members of the local parliament during the budgetary meeting

\begin{tabular}{|c|c|c|c|c|}
\hline $\begin{array}{l}\text { Speakers-Parliament } \\
\text { Member (PM) }\end{array}$ & $\begin{array}{l}\text { The illocution utterance Illocution } \\
\text { directive }\end{array}$ & $\begin{array}{l}\text { Politeness directive } \\
\text { Politeness markers } \\
\end{array}$ & $\begin{array}{l}\text { Shape of the } \\
\text { directive }\end{array}$ & Function of the directive \\
\hline \multirow[t]{4}{*}{ 1. PM-1 } & $\begin{array}{l}\text { 1. Pada kesempatan berbahagia siang } \\
\text { ini marilah kita panjatkan puji syukur } \\
\text { kehadirat Allah SWT } \\
\text { On this happy day, please let's thank } \\
\text { God }\end{array}$ & $\begin{array}{l}\text { 1....marilah kita } \\
\text { panjatkan puji syukur } \\
\text { kehadirat Allah } \\
\text {...please let's thank God }\end{array}$ & 1. Declarative & $\begin{array}{l}\text { 1. Mengajak melakukan } \\
\text { sesuatu Asking the hearer } \\
\text { to do something }\end{array}$ \\
\hline & $\begin{array}{l}\text { 2. Mangga saya persilakan eksekutif } \\
\text { untuk menanggapi satu persatu Please, } \\
\text { I'd like the executive to respond }\end{array}$ & $\begin{array}{l}\text { 2. Mangga saya } \\
\text { persilakan eksekutif... } \\
\text { Please, I'd like the } \\
\text { executive to respond }\end{array}$ & 2. Imperative & $\begin{array}{l}\text { 2. Memerintah melakukan } \\
\text { sesuatu secara langsung } \\
\text { dan halus Instructing the } \\
\text { hearer directly and softly }\end{array}$ \\
\hline & $\begin{array}{l}\text { 3. Yang ditanyakan itu anggaran } 2011 \\
\text { yang sudah dianggarkan dan } \\
\text { dilaksanakan, posisi anggaran seperti } \\
\text { apa? } \\
\text { Someone asked the } 2011 \text { budget that } \\
\text { had been budgeted and implemented, } \\
\text { what was the position of the budget } \\
\text { like? }\end{array}$ & $\begin{array}{l}\text { 3.... seperti apa? What } \\
\text { was the position of the } \\
\text { budget like? }\end{array}$ & 3. Interrogative & $\begin{array}{l}\text { 3. Meminta menjelaskan } \\
\text { sesuatu } \\
\text { Asking to clarify something }\end{array}$ \\
\hline & $\begin{array}{l}\text { 4. Jelaskan secara detil yang } 2011 \text { itu! } \\
\text { Explain in detail the } 2011 \text { budget! }\end{array}$ & $\begin{array}{l}\text { 4. The speaker used the } \\
\text { falling intonation to } \\
\text { command directly }\end{array}$ & 4. Imperative & $\begin{array}{l}\text { 4. Menyuruh langsung } \\
\text { untuk menjelaskan sesuatu } \\
\text { Instructing to explain } \\
\text { something directly }\end{array}$ \\
\hline 2. PM-2 & $\begin{array}{l}\text { 5. Cukup jelas, namun pelaksanaannya } \\
\text { kira-kira bulan apa? } \\
\text { It's clear enough, but in what month } \\
\text { will the activity be done? }\end{array}$ & $\begin{array}{l}\text { 5...pelaksanaannya } \\
\text { kira-kira bulan apa? } \\
\text {...what month will the } \\
\text { activity be done? }\end{array}$ & 5. Interrogative & $\begin{array}{l}\text { 5. Meminta memberi } \\
\text { informasi secara tak } \\
\text { langsung } \\
\text { Asking to give information } \\
\text { indirectly }\end{array}$ \\
\hline \multirow[t]{2}{*}{ 3. PM-3 } & $\begin{array}{l}\text { 6. Jadi mohon juga BKD untuk } \\
\text { menjelaskan kalau-kalau kita nanti } \\
\text { mendapatkan pertanyaan } \\
\text { So, please BKD explain if we will be } \\
\text { asked questions. }\end{array}$ & $\begin{array}{l}\text { 6. ...mohon juga BKD ... } \\
\text {... please BKD explain ... }\end{array}$ & 6. Request & $\begin{array}{l}\text { 6. Memohon memberi } \\
\text { penjelasan } \\
\text { Requesting to explain }\end{array}$ \\
\hline & $\begin{array}{l}\text { 7. Ada satu hal yang saya tanyakan, } \\
\text { apa mungkin ada ketentuan dari } \\
\text { BAKN berapa persen yang akan } \\
\text { diambil untuk tes itu? There is one } \\
\text { thing I asked: if it is possible that there } \\
\text { is a regulation from BAKN about how } \\
\text { large a percent of participants will be } \\
\text { recruited for the test? }\end{array}$ & $\begin{array}{l}\text { 7. ... apa mungkin } \\
\text { ada ...? } \\
\text { Berapa persen yang } \\
\text { akan......? } \\
\text { if it is possible that there } \\
\text { is... } \\
\text { How large a percent } \\
\text { will...? }\end{array}$ & 7. Interrogative & $\begin{array}{l}\text { 7. Meminta memberi } \\
\text { informasi } \\
\text { Asking to give information }\end{array}$ \\
\hline \multirow[t]{3}{*}{ 4. PM-4 } & $\begin{array}{l}\text { 8. Mungkin saya nambahi, pimpinan } \\
\text { Maybe I add explanation, chairman. }\end{array}$ & $\begin{array}{l}\text { 8. Mungkin saya } \\
\text { nambahi pimpinan } \\
\text { Maybe I add } \\
\text { explanation, chairman. }\end{array}$ & 8. Declarative & $\begin{array}{l}\text { 8. Meminta melakukan } \\
\text { sesuatu dengan menyela } \\
\text { Asking to do something by } \\
\text { interrupting }\end{array}$ \\
\hline & $\begin{array}{l}\text { 9. Ini berkaitan dengan pasar } \\
\text { Ir.Sukarno, disini saya usulkan untuk } \\
\text { koordinasi } \\
\text { It relates to the Sukarno market, which } \\
\text { I propose to coordinate. }\end{array}$ & $\begin{array}{l}\text { 9. ... saya usulkan untuk } \\
\text { koordinasi } \\
\text {... I propose to } \\
\text { coordinate. }\end{array}$ & 9. Declarative & $\begin{array}{l}\text { 9. Meminta melakukan } \\
\text { sesuatu secara tersirat } \\
\text { Asking to do something } \\
\text { implicitly }\end{array}$ \\
\hline & $\begin{array}{l}\text { 10. Perlu kita ketemu karena ada } \\
\text { sesuatu yang perlu kita bicarakan, } \\
\text { kalau klir ya sudah } \\
\text { We need to meet because there is } \\
\text { something we need to talk about. } \\
\text { Supposing it is clear, it's enough. }\end{array}$ & $\begin{array}{l}\text { 10. Perlu kita ketemu } \\
\text { karena ada sesuatu } \\
\text { yang perlu kita } \\
\text { bicarakan ... } \\
\text { We need to meet } \\
\text { because there is } \\
\text { something we need to } \\
\text { talk about }\end{array}$ & 10. Declarative & $\begin{array}{l}\text { 10. Meminta melakukan } \\
\text { sesuatu disertai alasan } \\
\text { tertentu dengan langsung } \\
\text { Askin directly to do } \\
\text { something with certain } \\
\text { reasons. }\end{array}$ \\
\hline
\end{tabular}


Table 2 shows linguistic elements that underline the politeness strategies for the directive speech acts performed by the members of local parliament. The lingual elements: illocution directive, marker of directive politeness utterance, shape of directive utterance, and function of directive utterance constitute an utterance unit containing an implicature. Gazdar (1979, p. 38) defines implicature as a proposition that is implied by an utterance in a certain context, even though the proposition was not explicitly said by the speaker. Table 3 gives examples of implicatures in politeness utterances for directive speech acts.

Table 3. Implicatures in politeness utterances for directive speech acts

\begin{tabular}{ll}
\hline $\begin{array}{l}\text { Speaker Parliament } \\
\text { member (PM) }\end{array}$ & $\begin{array}{l}\text { Politeness utterance for directive speech act } \\
\text { (Referring to the linguistic elements) }\end{array}$ \\
\hline 1. PM1 & $\begin{array}{l}\text { 1. Pada kesempatan berbahagia siang ini, marilah kita } \\
\text { panjatkan puji syukur kehadirat Allah SWT On this } \\
\text { happy day, please let's thank God. }\end{array}$
\end{tabular}

2. Mangga, saya persilakan eksekutif untuk menanggapi satu per-satu satu.

Please, I'd like the executive to respond one by one.

3. Yang ditanyakan itu anggaran 2011 yang sudah dianggarkan dan dilaksanakan, posisi anggarannya seperti apa?

Someone asked the budget 2011 that had been budgeted and implemented, what was the position of the budget like?

4. Jelaskan secara detil yang $2011 \mathrm{itu}$.

Explain in detail the 2011 budget

[spoken in low intonation].

2. PM-2

3. PM-3

\section{Cukup jelas, namun pelaksanaannya kira-kira} bulan apa?

It's clear enough, but in what month will the activity be done?

6. Jadi mohon juga BKD untuk menjelaskan kalau kita nanti mendapatkan pertanyaan.

So, please, BKD, explain if we will be asked questions

7. Ada satu hal yang saya tanyakan,apa mungkin ada ketentuan dari BAKN berapa persen yang akan diambil untuk tes itu?

There is one thing I asked: is it possible that there is a regulation from $B A K N$, about how large a percent of participants will be recruited for the the test?

4. PM-4 8. Mungkin saya nambahi pimpinan.

Maybe, I add explanation, chairman.

9. Ini berkaitan dengan pasar Ir.Sukarno, disini saya usulkan untuk koordinasi.

It relates to the Sukarno market, which I propose to coordinate.

10. Perlu kita ketemu karena ada sesuatu yang perlu kita bicarakan, kalau klir ya sudah.

We need to meet because there is something we need to talk about.

Supposing it's clear, it's enough.
Implicature of utterance

1. Mengajak langsung mitra tutur atau hadirin untuk bersyukur bersyukur kepada Tuhan Yang Maha Kuasa atas kebahagiaan yang diperoleh

Asking the hearers and attendants directly to express gratitude to God for the happiness they feel.

2. Meminta mitra tutur secara langsung dan lembut memberi penjelasan atas pertanyaan ataupun komentar dari beberapa penutur.

Asking the hearer directly but softly to respond to the questions or comments from the speakers.

3. Meminta tidak langsung kepada mitra tutur untuk menjelaskan/memberi gambaran tentang pemakaian anggaran tahun 2011 yang sudah diwujudkan. Asking the hearer indirectly to clarify whether the 2011 budget had been realized.

4. Memerintah secara langsung kepada mitra tutur untuk menjelaskan secara rinci pemanfaatan anggaran tahun 2011. Directly instruicting the hearer to explain the use of 2011 budget.

5. Meminta secara tidak langsung kepada mitra tutur memberi informasi waktu pelaksanaan kegiatan.

Asking the hearer indirectly to disclose the time that the intended activity will be done.

6. Memohon secara langsung kepada mitra tutur menjelaskan hal rekrutmen pegawai negeri, untuk antisipasi bila nanti dipermasalahkan pihak-pihak tertentu. Directly requesting the hearer to explain about the recruitment of civil servants and whether to anticipate the issues being questioned by the other party.

7. Meminta secara tidak langsung kepada mitra tutur memberi keterangan tentang ada tidaknya regulasi tentang prosentasi peserta yang akan direkrut dalam tes seleksi pegawai neegeri sipil.

Indirectly asking the hearer about a regulation affecting the percentage of participants will be recruited in the selection test of civil servants

8. Permintaan secara langsung dari penutur PM4 kepada penutur PM1 untuk memberi waktu menanggapi penjelasan dari mitra tutur_pihak eksekutif.

Speaker-PM4 asked directly speaker-PM1 to respond to the explanation of the hearer, the executive.

9. Permintaan tidak langsung kepada mitra tutur untuk melakukan koordinasi dengan penutur terkait masalah proyek pasar tradisional Ir.Soekarno.

Asking the hearer indirectly to do a coordination related to the project of to do a coordination related to the project of the traditional market in Sukoharjo.

10. Permintaan langsung dari penutur kepada mitra tutur untuk mengadakan pertemuan untuk membahas suatu masalah yang dianggap penting oleh pihak penutur _legislatif.

$\bar{A}$ sking directly from the speaker to hearer, to hold a meeting to an urgent issue in the view of the speaker, represendiscuss Asking directly, from the speaker to the hearer, to hold a meeting to discuss an urgent issue in the view of the speaker, representing the legislative party. 
Table 3 indicates the politeness utterances for directive speech acts, as constructed from the linguistic elements of Table 2 and related with their implicatures, which confer a nuance on the utterances. A nuance is related to the character of the utterance, which is essentially like an object in that it has characteristics and features, much like a rock has the characteristics of being hard and heavy. An utterance therefore has certain characteristics, and these derive not just from the linguistic elements but also other elements, such as the implicature. Accordingly, the politeness utterance for a directive speech act also has characteristics, and these determine what an instruction, direction, order, or request looks like.

\subsection{The Character of Directive Politeness Utterances by Members of Parliament}

The character of directive politeness utterances by members of parliament is colored by the shape and function of the utterance and non-lingual elements like the utterance strategy, the utterance's implicature, the context in which the interaction took place, what the topic of interaction was, and who the speaker was addressing. The character of a directive politeness utterance can be (1) inviting, gentle, and direct; (2) repressing, gentle, and direct; (3) suggesting, gentle, and indirect; (4) repressing, gentle, and indirect; (5) gentle and indirect; or (6) respecting and direct. See Table 4 for examples.

Table 4. The character of the politeness utterances for directive speech acts

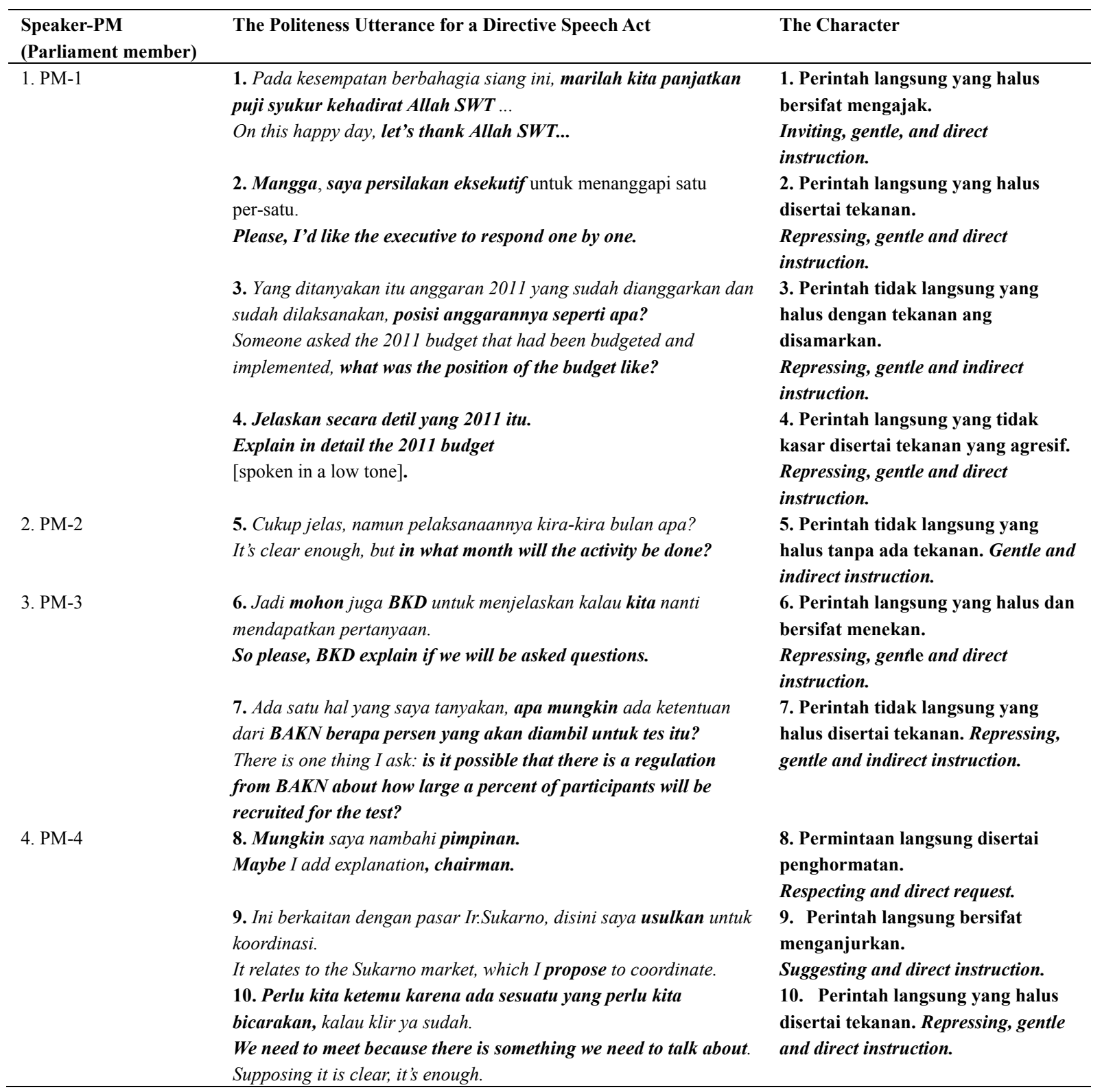


As Table 4 suggests, the direct-gentle and indirect-gentle approaches are vital for the politeness of directive speech acts, tending to arise in every politeness utterance for a directive speech act. The direct-gentle approach is indicated with the utterance shapes declarative and imperative. An indirect-gentle approach, meanwhile, is indicated with the interrogative utterance shape. The function of the directive utterance elicits special politeness in terms of inviting, suggesting, respecting, and repressing most frequently. The repressing mostly occurs in the directive speech act, because this makes its hearer feel uncomfortable because of the pressured manner. The repressing utterance is an example of a face-threatening act (Brown \& Levinson, 1987).

The special characteristics attached to the main utterance characters include direct-gentle or indirect-gentle. These are exemplified as inviting, gentle and direct (1); repressing, gentle and direct $(2,4,6,10)$; repressing, gentle and indirect (3, 7); gentle and indirect (5); respecting and direct (8); and suggesting and direct (9).

Evidently, the character of a politeness utterance in a directive speech act illustrates a political dimension. Indeed, utterances are affected by the political interests of their speakers, being representatives of their political party or government institution. Therefore, the politeness utterances in the directive speech acts performed by the speakers in the study was specified as a political directive politeness.

\section{Conclusion and Implications}

In summary, this study finds general evidence of politeness strategies for the directive speech acts of speakers in the proceedings of DPRD Sukoharjo. Three such strategies were observed: on record, negative politeness, and positive politeness. Speakers are more inclined to use the negative politeness strategy, but the positive politeness strategy covers the hearer and speaker in the activity and gives reason. In addition, the negative strategy comprises four approaches: questioning or hedging, minimizing the imposition, giving deference, and impersonalizing the speaker and hearers. The politeness strategies used by speakers could be recognized through the linguistic politeness markers they exhibited.

In particular, the characteristics that politeness utterances show in directive speech acts are basically similar to the attributes of an object, such as solid, liquid, soft, hard, thick, or thin, implying that generated utterances have special characteristics. The speakers utterance in this study are characterized by linguistic elements and non-linguistic elements. The linguistic elements comprise the shape and function of the utterance, while the non-linguistic elements comprise the utterance strategy, the utterance's implicature, and the utterance's context. In this study, the character of a politeness utterance in a directive speech act took one of the following forms: (1) inviting, gentle and direct; (2) repressing, gentle and, direct; (3) suggesting, gentle and indirect; (4) repressing, gentle and indirect; (5) gentle and indirect; (6) respecting and direct. Evidently, the character of a politeness utterance in a directive speech act illustrates that it contains a political dimension representing the political interests of the speaker according to his or her political party or parliamentary institution.

Pursuant to the results of this study, further research could compare or contrast findings of this study with the characteristics of utterances in directive speech acts in less formal situations, such as the interaction between a buyer and seller in a traditional market or the interaction between a religious cleric and his or her audience within a religious setting, such as a mosque, church, or synagogue.

\section{References}

Ambuyo, B. A., Indede, N. F., \& Karanja, P. N. (2011). Face Threatening Act and Standing Orders: 'Politeness' or 'Politics' in the Question Time Discussion of the Kenyan Parliament. International Journal of Humanities and Social Science, 1(9), 209-218.

Austin, J. L. (1962). How to Do Things with Words. London: Oxford University Press.

Ayeomoni, O. M., \& Akinkuolere, O. S. (2012). A pragmatic analysis of victory and inaugural speeches of President Umaru Musa Yar'Adua. Theory and Practice in Language Studies, 2(3), 461-468. https://doi.org/10.4304/tpls.2.3.461-468

Brown, P., \& Stephen, L. (1987). Politeness: Some Universals in Language Usage. Cambridge: Cambridge University Press. https://doi.org/10.1017/CBO9780511813085

Cheung, C. S. T. (2009). Politeness Strategies of Chinese and American Speakers (pp. 45-54). Hongkong: LCOM Papers 1. Retrieved August 29, 2014, from http://www.english.hku.hk/LCOM papersnew.rev/2009

Cutting, J. (2008). Pragmatics and Discourse. London \& New York: Routledge, Taylor \& Francis Group.

David, M. K., Hei, K. C., \& DeAlwis, C. (2012). Politenes Strategies in Openings and Closings of Service Encounters in Two Malaysian Agencies. Journal of the South East Asia Research Centre or Communication and Humanities, 4(2), 61-76. 
Gazdar, G. (1979). Pragmatics: Implicature, presuppositions and logical form. New York: Academic Press.

Goody, E. N. (1987). Questions and Politeness, Strategies in Social Interaction. Cambridge: Cambridge University Press.

Gunarwan, A. (2007). Pragmatik, Teori dan Kajian Nusantara (Kumpulan Makalah). Direktif di dalam Bahasa Indonesia, di Antara Beberapa Kelompok Etnik di Jakarta dalam PELLBA 5, Unika Atma Jaya., 23-24, Juli 1991. Jakarta: Penerbit Universitas Atma Jaya.

Huang, Y. (2007). Pragmatics. Oxford: Oxford Universtity Press.

Hymes, D., \& Gumpersz, J. J. (1986). Directions in Sociolinguistics: The Ethnography of Communication. Blackwell, Oxford.

Jarraya, S. (2013). Persuasion in political discourse: Tunisian president Ben Alis last speech as a case study. Master's Thesis. New York: Syracure University, Graduate School. Theses ALL Paper 4. Retrieved from http://surface.syr.edu/Thesis

Karafoti, E. (2007). Politeness, Gender and the Face ofthe Speaker (pp. 120-126). Greece: Linguistic Department Aristotle University of Thessalonki.

Lakoff, R. (1973). The Logic of Politeness; or Minding your P's and Q's. Dalam Papers from the Ninth Regional Meeting of the Chicago Linguistic Society (pp. 292-305). Chicago: Chicago Linguistic Society.

Langton, R. (1993). Speech acts and unspeakable acts. Philosophy \& Public Affairs, 22(4), 293-330. Retrieved from http://www.jstor.org

Leech, G. (1993). Prinsip-Prinsip Pragmatik (Diterjemahkan oleh M.D.D. Oka dan Setyadi Setyapranata). Jakarta: Penerbit Universitas Indonesia.

Levinson, S. (1983). Pragmatics. London: Cambridge University Press. https://doi.org/10.1017/CBO9780511813313

MacMillan, J. H., \& Schumacher, S. (2001). Research in Education, A Conceptual Introduction. New York \& London: Penerbit Longman.

Palonen, K. (2016). From oratory to debate: Parliamentarisation of deliberative rhetoric in Westminster. Germany: Nomos. https://doi.org/10.5771/9783845272962

Pishghadam, R., \& Navari, S. (2012). A Study into Politeness Strategies and Politeness Markers in Advertisements as Persuasive Tools. Mediterranean Journal of Social Sciences, 3(2), 12-13.

Prayitno, H. J. (2009). Perilaku Tindak Tutur Berbahasa Pemimpin dalam Wacana Rapat Dinas: Kajian Pragmatik Dengan Pendekatan Jender. Jurnal Kajian Linguistik dan Sastra, 21(2), 132-146.

Santosa, R. (2012). Metode Penelitian Kualitatif Kebahasaan. Surakarta: Fakultas Sastra dan Seni Rupa Universitas Sebelas Maret.

Searle, J. R. (1974). Speech Acts, An Essay in The Philosophy of Language. Cambridge: Cambridge University Press.

Shigemetsu, Y., Murata, Y., \& Otsuka, Y. (2006). Positive Politeness Strategies in Everyday Japanese Conversation. ACADEMIC REPORTS Fac. Eng, 29(2). Tokyo Polytechnic University.

Spradley, J. P. (1980). Participant Observation. New York: Holt and Winston.

Sudaryanto. (1993). Metode and Aneka Teknik Analisis Bahasa. Jogjakarta: Duta Wacana University Press.

Thomas, J. (1995). Meaning in Interaction: An Introduction to Pragmatics. New York: Longman

Yule, G. (1996). Pragmatics. Oxford: Oxford University Press.

\section{Copyrights}

Copyright for this article is retained by the author, with first publication rights granted to the journal.

This is an open-access article distributed under the terms and conditions of the Creative Commons Attribution license (http://creativecommons.org/licenses/by/4.0/). 